\title{
The Impact of Social Media Marketing on Purchase Intention in a Transition Economy: The Mediating Role of Brand Awareness and Brand Engagement
}

\author{
Adelina Emini \\ Faculty of Economics, University of Pristina, Kosovo \\ Jusuf Zeqiri \\ Faculty of Business and Economics, South East European University, North \\ Macedonia
}

\begin{abstract}
The study aimed to investigate the impact of social media marketing on purchase intention among consumers in Kosovo as a transition economy. The survey research has been conducted with a sample of 334 respondents in Kosovo, using an online survey tool for response collection. Structural equation modeling was used for assessing the proposed theoretical model. The bootstrapping technique was used to test the hypotheses and the mediating effects of brand awareness and brand engagement. The findings revealed a positive indirect impact of social media marketing on purchase intention and a full mediating effect of brand awareness and brand engagement in the relationship between social media marketing and purchase intention. The contribution of this study is that it provides insights into the impact of social media marketing on brand awareness, brand engagement, and purchase intention in transition economies. Moreover, it highlights the impact of social media marketing on enhancing brand awareness, brand engagement, and purchase intention in emerging economies in general and in particular in Kosovo. On a practical level, research results provide customers' insights relevant for designing effective social media marketing strategies for their potential prospects in transition economies.
\end{abstract}

Keywords: social media marketing, brand awareness, brand engagement, purchase intention, transition economy

JEL classification: M30; M31

Paper type: Research article

Received: Apr 23, 2021

Accepted: Aug 1 1, 2021

DOI: $10.54820 / F D O R 9238$ 


\section{Introduction}

The new advances in communication technologies have transformed the way companies decide to communicate with their target consumers and clients. Internet technologies offer companies more opportunities that enable companies besides their mass marketing communication strategies to reach their prospects with more customized marketing mix strategies. Scholars nowadays try to explore the impact that various digital tools have on their customers. In this line more and more companies are interested in using digital marketing as a new way of delivering superior value to their targets. Even the positioning strategies have become easier with the support of digital strategies. Social media platforms have eased the interaction of humans recently (Balakrishnan et al., 2014). Therefore, companies use different tools for digital marketing communication, such as search engine optimization, content marketing, social media platforms, etc. which proves to be very effective and efficient. Therefore, this new form of communication offers more opportunities and more challenges at the same time (Laksamana, 2018).

The new way of communicating with target markets has posed some new challenges for companies in general, and especially for companies that operate in emerging markets, such as the Kosovo market. Since consumers now have more information which provides them with more power, henceforth making pressure on companies on the way how they communicate and promote their marketing offerings. As a result, companies had to look at new ways of combining the existing marketing communication activities with communication techniques that embed technology. Social media marketing has become a very crucial marketing tool to reach emerging generations of consumers that are savvy with technology (Balakrishnan et al., 2014).

According to some estimates, there are around 1.76 million internet users in Kosovo, and the penetration rate is 91 percent. There are 1.10 million social media users in Kosovo, representing $56.9 \%$ of the population that uses any social media platform (Kemp, 2021). Concerning age generation and platform users, age groups between 25-34 years old are more active on Facebook, Instagram, and Linkedln, whereas 18-24 use more on Snapchat.

The topic of digital marketing has been researched a lot recently, but still, there is little research on the impact of social media marketing in emerging markets in general, and especially in the Kosovo market.

More specifically, the main aim of this research is to explore the impact of social media marketing, brand awareness, and brand engagement on purchase intention. In addition, the research tries to analyze whether brand awareness and customer engagement mediate the relationship between social media marketing and purchase intention.

The paper commences with an introduction to the research problem. The following section reviews the relevant literature regarding social media marketing, brand awareness, brand engagement, and purchase intention. Next, the methodology and empirical findings are presented. The final section deals with the discussion and conclusion.

\section{Literature review}

From a company perspective, the proliferation of social media marketing helps them reach their target customers using any of the social media platforms. This kind of interaction provides companies with customer insights to assess customers' journeys in different stages of the adoption process. From a consumer's perspective, the use of these digital technologies offers customers many benefits, such as useful 
information, efficiency, comparing products and services, comparing prices, convenience, variety of products, etc. (Tiago et al., 2014). Companies in the past used to engage their customers through many forms of traditional marketing communication tools including television, radio, direct marketing, telemarketing to disseminate information about their products or services. Consumer behavior has changed a lot concerning technology adoption, and as a result, consumers nowadays prefer to use the internet for getting and sharing information, getting feedback, and reviewing products and services.

Social media platform seems to enhance consumer interaction more proactively, and companies should use social media marketing to communicate with consumers as well (Tiago et al., 2014).

The popularity of social media is rising every day. People can communicate with each other about anything that interests them in this digital environment. More importantly, people talk and share experiences about products and services they buy and consume (Gray et al., 2018). This makes social media marketing a very valuable tool for companies to promote their marketing offers.

Social media has become a very popular place for finding information, since people post information, videos, photos, and other posts using different social media, including Facebook, Instagram, Linkedln, Pinterest, and others.

Organizations can use different social media marketing strategies, a passive approach focusing on using social media as a source of customer insights, and as a source of customer engagement (Constantinides, 2014).

Based on the above literature review a conceptual framework is proposed with purchase intention as a dependent variable, and brand awareness, customer engagement as independent variables. Therefore, the hypothesized relationship between these variables is depicted in Figure 1.

Figure 1

Research concept model

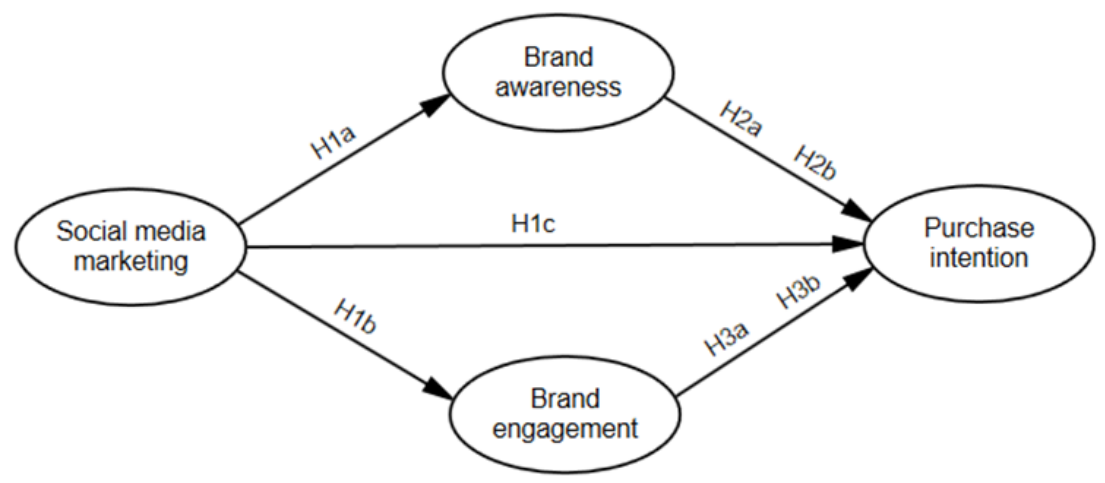

Source: Author's work

\section{Hypotheses development}

Social Media Marketing

Information technologies have changed the way people and companies communicate and interact. Nowadays consumers use social media platforms to interact and share information with others. The increased number of social users has forced companies to find new ways to communicate with their target markets. As a result of social media, an expansion made companies more active with digital marketing activities for their marketing purposes (Çizmeci et al., 2015). 
Organizations use many social media platforms. This kind of digital marketing strategy enables companies to build customer relationships (Patrutiu-Baltes, 2016). A lot of studies point out the impact that social media marketing has on brand awareness (Seo et al., 2018; Ansari et al., 2019), brand engagement (Holliman et al., 2014; Meire et al., 2019), and invoking purchase intention. Therefore, the following hypotheses are postulated as follows:

- Hla: Social media marketing impacts significantly brand awareness

- Hlb: Social media marketing impacts significantly brand engagement

- Hlc: Social media marketing impacts significantly purchase intention

\section{Brand Awareness}

Companies use their brands to distinguish their products and services from other competitors. Brands embody in themselves new names, symbols or, logos for new products or services (Keller, 2008). Branding is all about differentiating products and services from other offers in a given market (Kotler et al., 2016). Brand awareness helps consumers decrease the time spent during the search process for a product (Verbeke et al., 2005).

Social media marketing (SMM) facilitates the process of brand awareness for consumers. A lot of studies point out the link between social media marketing usage and brand awareness. Momany et al. (2016) indicate a strong link between social media communication efforts and brand awareness. Social media marketing is seen as a trendiness component of communication which has a significant effect on brand awareness (Seo et al., 2018). In addition, other recent studies like Ansari et al. (2019); Jamali et al. (2018); Ezenwafor et al. (2021); Aljumah et al. (2021), also support the correlation between social media marketing and brand awareness. Therefore, based on the above we propose the following hypothesis:

- H2a: Brand awareness impacts significantly purchase intention

- H2b: Brand awareness mediates the relationship between SMM and purchase intention

\section{Brand engagement}

There are different definitions concerning what comprises customer engagement. The former is linked with the value perceived by the customer during interaction with the brand (Gambetti et al., 2012; Brodie et al., 2013; Bowden, 2009) and the latter represents the interaction of consumers with the product and organization (Kumar et al., 2010; Verhoef et al., 2010). The rapid diffusion of social media communication influenced the process of interaction between people, the way they communicate and interact with one another (Tiago et al., 2014).

Many studies point out that customer engagement leads to purchase intention. Brand engagement moderates the impact of SMM on consumer purchase intention (Husnain et al., 2017; Meire et al., 2019; Chen et al., 2019: Pansari et al., 2017). Therefore, the following hypotheses are postulated as follows:

- H3a: Brand engagement impacts significantly purchase intention

- H3b: Brand engagement mediates the relationship between SMM and purchase intention

\section{Methodology}

This study used a structured questionnaire to investigate the effect of social media marketing on brand awareness, brand engagement, and purchase intention. The study tried also to reveal the mediating effect of both brand awareness and brand engagement on the relationship between social media marketing and purchase 
intention in Kosovo. A convenience sampling technique was used to collect the data. The data was collected from March to May 2021.

Respondents were asked to respond to the structured questionnaire with a 5-point Likert scale and distributed using online google forms. The first part of the questionnaire provided demographic data of respondents and the second part customer perceptions toward the impact of SMM on BA, BE, and PI.

Table 1 shows the respondents' characteristics. Of the respondents, 121 were males (36.2\%), and 213 were females (63.8\%). Concerning age, $99(29.6 \%)$ were under 20. Most respondents were 21 to 30 years of age, or $177(53.0 \%)$ of the sample, $45(13.5 \%)$ were 31 to $40,7(2.1 \%)$ were 41 to 50 , and $6(1.8 \%)$ were more than 51 . Regarding respondents' social media experience $4(1.2 \%)$ were with 1 to 2 years of social media experience, $45(13.5 \%)$ with 3 to 4 years of social media experience, 82 $(24.6 \%)$ with 5 to 6 years of social media experience, and the majority of respondents $203(60.8 \%)$ were with more than 7 years of social media experience. More than half of the respondents were college students 154 (46.1\%), 102 (30.5\%) working full-time, $52(15.6 \%)$ working part-time and going to college, 26 (7.8\%) working part-time only.

Table 1

Demographic profile

\begin{tabular}{llrr}
\hline & & Frequency & Percent \\
\hline Gender & Male & 121 & 36.2 \\
\hline \multirow{2}{*}{ Age } & Female & 213 & 63.8 \\
& Under 20 & 99 & 29.6 \\
& $21-30$ & 177 & 53.0 \\
& $31-40$ & 45 & 13.5 \\
\hline \multirow{3}{*}{ Social media experience } & $41-50$ & 7 & 2.1 \\
& More than 51 & 6 & 1.8 \\
\cline { 2 - 4 } & 1 to 2 years & 4 & 1.2 \\
& 3 to 4 years & 45 & 13.5 \\
\hline \multirow{3}{*}{ Occupation } & 5 to 6 years & 82 & 24.6 \\
& More than 7 years & 203 & 60.8 \\
\hline & Part-time & 154 & 46.1 \\
& Working full-time & 102 & 30.5 \\
\hline & Working part-time and going to college & 52 & 15.6 \\
\hline & Working part-time only & 26 & 7.8 \\
\hline
\end{tabular}

Source: Author's calculation based on results

Structural equation modeling (SEM) is used to test observant and latent variables. We used a two-step strategy for assessing the measurement model and the structural equation modeling. The SEM technique was used to evaluate the measurement model (validity and reliability of the measures) and to estimate the structural model. A bootstrapping method was used for testing the significance of the path coefficients and the factor loadings (Hair et al., 2016).

\section{Results}

\section{Measurement model, reliability, and validity}

To calculate the scale reliabilities of the four constructs, Cronbach's alpha was used. The proposed threshold of 0.70 or greater reliability coefficient indicates od reliability (Hair et al., 2014). As it can be seen in table 2, Cronbach alpha for all constructs is above 0.7 recommended threshold (Ursachi et al., 2015).

This study used SEM to analyze the proposed research model. Further, SEM was used to test hypotheses and validate the conceptual model. The SEM technique 
evaluates $R^{2}, \beta$, and t-values (Zeqiri et al., 2020) to assess the model fit. Therefore, the SEM technique is used to evaluate the measurement model and to estimate the structural model. The obtained results from CFA showed that chi-square/df was 2.071 indicating satisfactory fit; a ratio of five or less is a good fit (Wheaton et al., 1977), CFI (0.971), GFI (0.949), AGFI (0.919), NFI (0.945), TLI (0.960), and RMSEA (0.057) all denote an adequate fit of the model.

To test the normality of the data, all VIF values are used to check if the model is biased. VIF values greater than 3.3 indicate a collinearity problem (Kock, 2015). Thus, the results denote that the model has a normal fit of the data (Table 2).

Table 2

Construct items

\begin{tabular}{|c|c|c|c|c|c|c|}
\hline Construct & & Loadings & Mean & STDEV & VIF & AVE \\
\hline $\begin{array}{l}\text { Social } \\
\text { media } \\
\text { marketing }\end{array}$ & Cronbach alpha (0.726) & & & & & 0.477 \\
\hline SMM1 & $\begin{array}{l}\text { Social media advertising draws } \\
\text { my attention to brands. }\end{array}$ & 0.679 & 3.796 & 1.068 & 1.812 & \\
\hline SMM2 & $\begin{array}{l}\text { Social media provides me with } \\
\text { information that I need for brands. }\end{array}$ & 0.707 & 3.883 & 0.884 & 1.804 & \\
\hline SMM3 & $\begin{array}{l}\text { It is interesting to see } \\
\text { information on brands through } \\
\text { social media. }\end{array}$ & 0.691 & 3.832 & 0.861 & 1.765 & \\
\hline $\begin{array}{l}\text { Brand } \\
\text { awareness }\end{array}$ & Cronbach alpha (0.850) & & & & & 0.580 \\
\hline BA1 & $\begin{array}{l}\text { Brand awareness is easier } \\
\text { through social media. }\end{array}$ & 0.749 & 3.775 & 0.917 & 2.020 & \\
\hline BA2 & $\begin{array}{l}\text { Social media offer more } \\
\text { characteristics about brands. }\end{array}$ & 0.827 & 3.823 & 0.947 & 2.603 & \\
\hline BA3 & $\begin{array}{l}\text { Brands through social media are } \\
\text { easily remembered. }\end{array}$ & 0.683 & 3.817 & 0.897 & 1.990 & \\
\hline BA4 & $\begin{array}{l}\text { Social media helps me } \\
\text { recognize brands }\end{array}$ & 0.813 & 3.892 & 0.894 & 2.825 & \\
\hline $\begin{array}{l}\text { Brand } \\
\text { engagement }\end{array}$ & Cronbach alpha (0.800) & & & & & 0.539 \\
\hline BE1 & $\begin{array}{l}\text { I have close relations on social } \\
\text { media with those who use the } \\
\text { same brands }\end{array}$ & 0.827 & 3.063 & 1.031 & 2.190 & \\
\hline BE2 & $\begin{array}{l}\text { I get engaged through social } \\
\text { media in brand activities }\end{array}$ & 0.683 & 3.395 & 0.943 & 2.108 & \\
\hline BE3 & $\begin{array}{l}\text { Social media makes me feel } \\
\text { positive toward a brand }\end{array}$ & 0.813 & 3.021 & 0.960 & 2.257 & \\
\hline $\begin{array}{l}\text { Purchase } \\
\text { intention }\end{array}$ & Cronbach alpha (0.807) & & & & & 0.586 \\
\hline PI1 & $\begin{array}{l}\text { I plan to purchase a brand that I } \\
\text { see on social media }\end{array}$ & 0.799 & 3.174 & 1.013 & 2.236 & \\
\hline PI2 & $\begin{array}{l}\text { I used to recommend a brand } \\
\text { that I like to others through social } \\
\text { media. }\end{array}$ & 0.752 & 3.470 & 0.970 & 2.038 & \\
\hline $\mathrm{PI} 3$ & $\begin{array}{l}\text { I intend to buy a brand that I like } \\
\text { based on social media discussions }\end{array}$ & 0.745 & 3.207 & 0.984 & 2.090 & \\
\hline
\end{tabular}

Source: Author's calculation based on results 
Convergent validity examines how close items relate to each other in a construct. (Becker et al., 2013). Convergent validity is usually tested by assessing the loadings, average variance extracted (AVE), and composite reliability.

Cronbach's alpha for social media marketing construct is $0.726,0.850$ for brand awareness, 0.800 for brand engagement, and 0.807 for purchase intention. The results reveal that all four constructs had reliability coefficients greater than the proposed threshold of 0.70. Convergent validity is reached if the factor loading exceeds the 0.7 thresholds and the average variance extracted (AVE) exceeds 0.5.

Discriminant validity examines how items in one construct are different from the item in other constructs. differ statistically from other item constructs (Zeqiri, 2020). As it can be seen in Table 2, the AVE is greater than 0.5 for all constructs, except Social $M M$ which is 0.477 . Therefore, achieving discriminant and convergent validity, the square root of the AVE should be greater than the correlations among the constructs (Table 3)

Table 3

Discriminant validity

\begin{tabular}{lcccc}
\hline Construct & SMM & BA & BE & PI \\
\hline Social media marketing (SMM) & $\mathbf{0 . 6 9 1}$ & & & \\
Brand awareness (BA) & 0.668 & $\mathbf{0 . 7 6 2}$ & & \\
Brand engagement (BE) & 0.587 & 0.528 & $\mathbf{0 . 7 3 4}$ & \\
Purchase intention (PI) & 0.571 & 0.535 & 0.672 & $\mathbf{0 . 7 6 5}$ \\
\hline
\end{tabular}

Note: Squared correlations; AVE in the diagonal.

Source: Author's calculation based on results

\section{Structural Model Estimation}

As shown in Figure 2, the $R^{2}$ ( $R$ Square) for the proposed research model is estimated that purchase intention variance is explained by 75 percent, brand awareness is explained by 71 percent of its variance, and brand engagement is explained by 58 percent of its variance by the model.

Table 4 shows the results of the path coefficients of the constructs. The results in indicate that social media marketing positively affected brand awareness with path coefficient $=0.975$, $t$-value $=10.391, \mathrm{p}<0.000$ ). Thus, $\mathrm{Hla}$ is supported. $\mathrm{HIb}$ is also supported, social media marketing positively affects brand engagement with path coefficient $=0.997, t$-value $=10.119$. The results reveal that social media marketing does not have any significant impact on purchase intention, with path coefficient = $0.190, \mathrm{t}$-value $=0.400, \mathrm{p}<0.409$ ). Thus, $\mathrm{hl} \mathrm{c}$ is not supported. The results in table 5 also show that brand awareness does not have any effect on purchase intention, with path coefficient $=0.071$, $t$-value $=0.486, p<0.627$ ). Thus, h2a is not supported. Finally, the results show that brand engagement has a significant positive effect on purchase intention, with path coefficient $=0.0739$, $t$-value $=6.688, p<0.000$ ). Thus, h3a is supported. 
Figure 2

Structural Equation Model

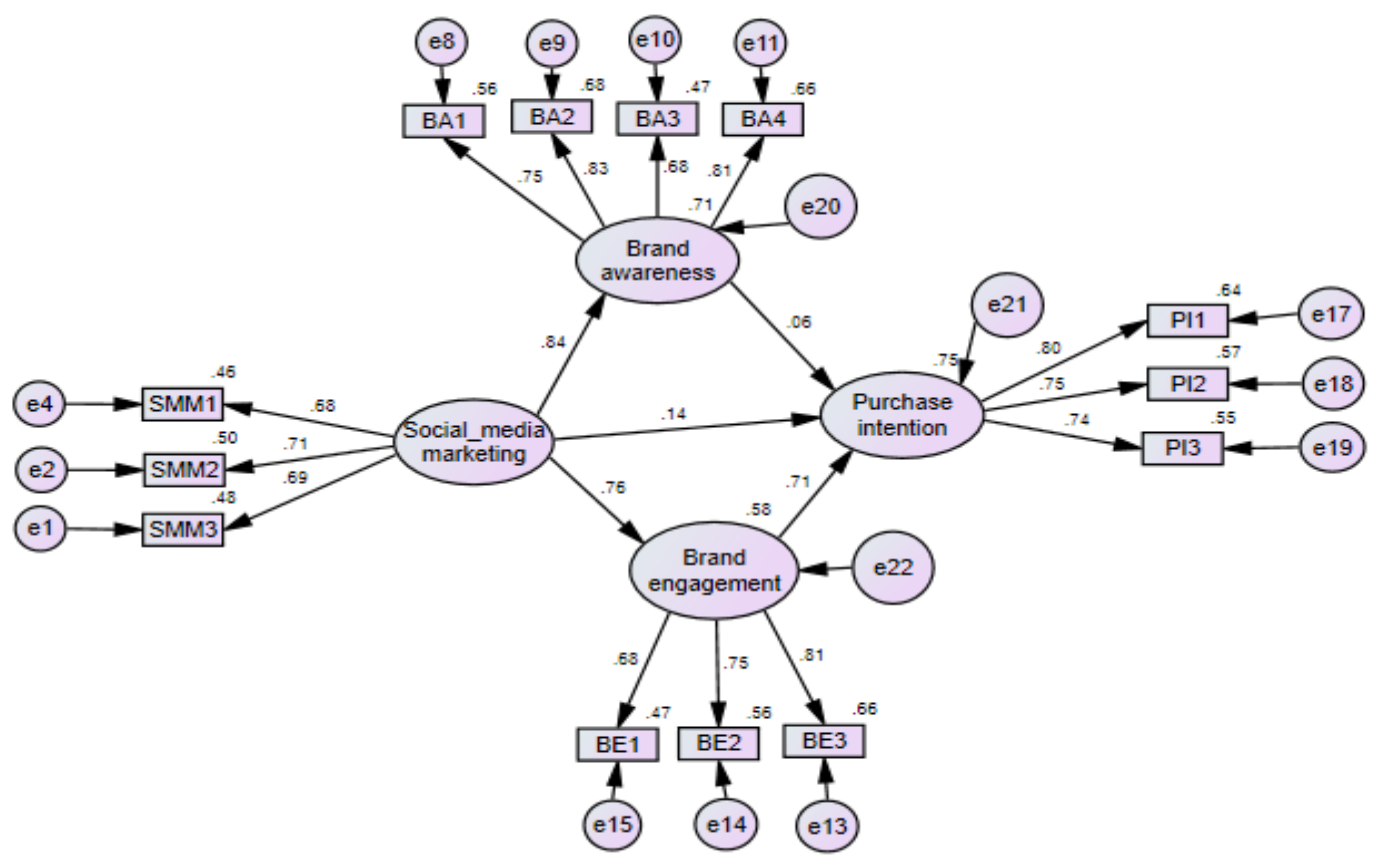

Source: Authors' work

Table 4

Hypotheses testing

\begin{tabular}{|c|c|c|c|c|c|c|}
\hline Hypotheses & & & Estimate & S.E. & C.R. & Conclusion \\
\hline $\begin{array}{l}\text { H1a. } \\
\text { Brand_awareness }\end{array}$ & $<$ & $\begin{array}{l}\text { Social_media } \\
\text { marketing }\end{array}$ & 0.975 & 0.094 & $10.391^{* * *}$ & Hla supported \\
\hline $\begin{array}{l}\text { H1b. } \\
\text { Brand_engagement }\end{array}$ & $<$ & $\begin{array}{l}\text { Social_media } \\
\text { marketing }\end{array}$ & 0.997 & 0.099 & $10.119^{* * *}$ & H1b supported \\
\hline $\begin{array}{l}\text { Hlc. } \\
\text { Purchase_intention }\end{array}$ & $<$ & $\begin{array}{l}\text { Social_media } \\
\text { marketing }\end{array}$ & 0.190 & 0.231 & 0.826 & Hlc not supported \\
\hline $\begin{array}{l}\mathrm{H} 2 \mathrm{a} . \\
\text { Purchase_intention }\end{array}$ & $<$ & $\begin{array}{l}\text { Brand_aware } \\
\text { ness }\end{array}$ & 0.071 & 0.146 & 0.486 & $\begin{array}{l}\text { H2a not } \\
\text { supported }\end{array}$ \\
\hline $\begin{array}{l}\text { H3a. } \\
\text { Purchase_intention }\end{array}$ & $<$ & $\begin{array}{l}\text { Brand_engag } \\
\text { ement }\end{array}$ & 0.739 & 0.111 & $6.688^{* * *}$ & H3a supported \\
\hline
\end{tabular}

Source: Author's calculation based on results

\section{Mediation effect of brand awareness and brand engagement}

A mediation effect analysis was used to find out if there are any mediation effects of brand awareness and brand engagement on the relationship between social media marketing and purchase intention. The results were based on factor loading and $\mathrm{p}$ values.

Table 5

Mediation Effect of Brand Awareness and Brand Engagement

\begin{tabular}{lrrrrc}
\hline Hypotheses & Estimate & \multicolumn{1}{c}{ Lower } & Upper & p-Value & Label \\
\hline H3a. Indirect effect_BA & 0.069 & -0.316 & 0.386 & 0.637 & No mediation \\
\hline H3b. Indirect effect_BE & 0.737 & 0.461 & 1.236 & 0.000 & Full mediation \\
\hline
\end{tabular}

Source: Author's calculation based on results 
Table 5 reveals that brand awareness showed no mediation effect on the relationship between social media marketing and purchase intention. Thus, $\mathrm{H} 3 \mathrm{a}$ is not supported. Brand engagement mediates fully the relationship between social media marketing and purchase intention as seen from results, path coefficient 0.737 and $\mathrm{p}$-value $=0.000$. Thus, supporting H3b.

\section{Discussion and conclusion}

This study explores the effect of social media marketing on purchase intention in Kosovo by deploying a model consisting of three independent variables related to social media marketing, brand awareness, and brand engagement, and a dependent variable related to purchase intention.

Social media marketing was positively and significantly related to brand awareness, corresponding to many studies that explored the impact of social media marketing on brand awareness such as Seo et al. (2018), Ansari et al. (2019), Jamali et al. (2018), Ezenwafor et al. (2021), Aljumah et al. (2021) and other studies.

The findings also revealed that social media marketing was positively related to brand engagement. The findings are also supported by other studies including Kumar, et al. (2010) and Verhoef et al. (2010). The findings did not show any positive relationship between social media marketing and purchase intention.

Moreover, the findings also reveal that brand awareness did not show any positive and significant impact on purchase intention. On the other hand, brand engagement showed to be positively and significantly related to purchase intention, corresponding with other studies such as Husnain et al. (2017), Meire et al. (2019), Chen et al. (2019), Pansari et al. (2017), and other studies.

Our findings revealed also the mediation effect that brand engagement has on the relationship between social media marketing and purchase intention. Moreover, brand awareness did not mediate the relationship between social media marketing and purchase intention.

Our study is unique in that it contributes to the research of social media marketing in emerging markets. The study offers customer insights concerning consumer behavior regarding the influence that social media marketing has on purchase intention. The study provides some interesting facts that even though social media marketing enhances brand awareness but does not necessarily mean that consumers being aware of certain brands would buy them at the end unless they are engaged or linked with the brand. Companies need to try to engage consumers since the results revealed that brand engagement leads to purchase intention.

The findings also provide organizations with some insights on how to deploy digital marketing strategies in emerging markets to reach consumers to promote their products and to engage them to purchase.

Despite this study's contributions to literature, it has several limitations. First, we used a convenience sample. Second, the sample size is from only one country, which makes the results very difficult to generalize in other countries. Future research is recommended to focus on cross-national analysis by performing multi-group analysis to check similarities and differences about consumers' perceptions in different countries concerning the effect that social media marketing has on purchase intention.

\section{References}

1. Aljumah, A., Nuseir, M. T., Alshurideh, M. T. (2021), "The Impact of Social Media Marketing Communications on Consumer Response During the COVID-19: Does the Brand Equity of 
a University Matter. The Effect of Coronavirus Disease (COVID-19) on Business Intelligence", Studies in Systems, Decision, and Control, Vol. 334, pp. 367-384.

2. Ansari, S., Ansari, G., Ghori, M. U., Kazi, A. G. (2019), "Impact of brand awareness and social media content marketing on consumer purchase decision", Journal of Public Valve and Administrative Insight, Vol. 2 No. 2, pp. 5-10.

3. Balakrishnan, B. K., Dahnil, M. I., Yi, W. J. (2014), "The impact of social media marketing medium toward purchase intention and brand loyalty among generation Y", ProcediaSocial and Behavioral Sciences, Vol. 148, pp. 177-185.

4. Becker, J. M., Rai, A., Ringle, C. M., Völckner, F. (2013), "Discovering unobserved heterogeneity in structural equation models to avert validity threats", MIS quarterly, Vol. 37 No. 3, pp. 665-694.

5. Bowden, J. L. H. (2009), "The process of customer engagement: A conceptual framework", Journal of marketing theory and practice, Vol. 17 No. 1, pp.63-74.

6. Brodie, R. J., Ilic, A., Juric, B., Hollebeek, L. (2013), "Consumer engagement in a virtual brand community: An exploratory analysis", Journal of business research, Vol. 66 No. 1, pp. 105-114.

7. Chen, J., XU, W. (2019), "A study on the impact of customer engagement on continued purchase intention for online video websites VIP service", in ICMSEM 2019: Proceedings of the Thirteenth International Conference on Management Science and Engineering Management, pp. 668-682.

8. Çizmeci, F., Ercan, T. (2015), "The Effect of Digital Marketing Communication Tools in the Creation Brand Awareness By Housing Companies", Megaron, Vol. 10 No. 2, pp. 149-161.

9. Constantinides, E. (2014), "Foundations of social media marketing", Procedia-Social and behavioral sciences, Vol. 148, pp. 40-57.

10. Ezenwafor, E. C., Ayodele, A. A., Nwaizugbo, C. I. (2021), "Social Media Marketing and Brand Loyalty Among Online Shoppers in Anambra State, Nigeria: Mediating Effect of Brand Awareness", Journal of Electronic Commerce in Organizations (JECO), Vol. 19 No. 3, pp. 16-27.

11. Gambetti, R. C., Graffigna, G., Biraghi, S. (2012), "The grounded theory approach to consumer-brand engagement: The practitioner's standpoint", International Journal of Market Research, Vol. 54 No. 5, pp. 659-687.

12. Gray, N., Fox, M. (2018), Social Media Marketing, Noah Gray.

13. Hair, Jr, J. F., Hult, G. T. M., Ringle, C., Sarstedt, M. (2016), A primer on partial least squares structural equation modeling (PLS-SEM), Sage publications.

14. Hair, J. F., Hult, G. T. M., Ringle, C. M., Sarstedt,M. (2014), A primer on partial least squares structural equation modeling (PLS-SEM), Sage Publication, Los Angeles.

15. Holliman, G., Rowley, J. (2014), "Business to business digital content marketing: marketers' perceptions of best practice", Journal of research in interactive marketing, Vol. 8 No. 4 , pp. 269-293.

16. Husnain, M., Toor, A. (2017), "The impact of social network marketing on consumer purchase intention in Pakistan: Consumer engagement as a mediator", Asian Journal of Business and Accounting, Vol. 10 No. 1, pp. 167-199.

17. Jamali, M., Khan, R. (2018), "The impact of consumer interaction on social media on brand awareness and purchase intention! Case study of Samsung", Journal of Marketing \& Logistics, Vol. 1 No. 1, pp. 125-140.

18. Keller, K. L. (2008), Strategic brand management: Building, measuring, and managing brand equity, Person Education, Upper Saddle River, New Jersey.

19. Kemp, S. (2021), "Digital 2921: Kosovo", available at: https://datareportal.com/reports/digital-2021-kosovo (19 July 2021)

20. Kock, N. (2015), "Common method bias in PLS-SEM: A full collinearity assessment approach", International Journal of e-Collaboration (ijec), Vol. 11 No. 4, pp. 1-10.

21. Kotler, P., Keller, K. L., Manceau, D., Dubois, B. (2016), Marketing Management, Pearson Education, New Jersey.

22. Kumar, V., Aksoy, L., Donkers, B., Venkatesan, R., Wiesel, T., Tillmanns, S. (2010), "Undervalued or overvalued customers: Capturing total customer engagement value", Journal of service research, Vol. 13 No. 3, pp. 297-310. 
23. Laksamana, P. (2018), "Impact of social media marketing on purchase intention and brand loyalty: Evidence from Indonesia's banking industry", International Review of Management and Marketing, Vol. 8 No. 1, pp. 13-18.

24. Meire, M., Hewett, K., Ballings, M., Kumar, V., Van den Poel, D. (2019), "The role of marketer-generated content in customer engagement marketing", Journal of Marketing, Vol. 83 No. 6, pp. 21-42.

25. Momany, M., Alshboul, A. (2016), "Social Media Marketing: Utilizing Social Media to Advance Brand Awareness and Increase Online Sales", International Journal of Business, Marketing, \& Decision Science, Vol. 9 No. 1, pp. 33-54.

26. Pansari, A., Kumar, V. (2017), "Customer engagement: the construct, antecedents, and consequences", Journal of the Academy of Marketing Science, Vol. 45 No. 3, pp. 294311.

27. Patrutiu-Baltes, L. (2016), "Inbound Marketing-the most important digital marketing strategy. Bulletin of the Transilvania University of Brasov", Economic Sciences. Series V, Vol. 9 No. 2, pp. 61-68.

28. Seo, E. J., Park, J. W. (2018), "A study on the effects of social media marketing activities on brand equity and customer response in the airline industry", Journal of Air Transport Management, Vol. 66, pp. 36-41.

29. Tiago, M. T. P. M. B., Verissimo, J. M. C. (2014), "Digital marketing and social media: Why bother?", Business horizons, Vol. 57 No. 6, pp. 703-708.

30. Ursachi, G., Horodnic, I.A., Zait, A. (2015), "How reliable are measurement scales? External factors with indirect influence on reliability estimators", Procedia Economics and Finance, Vol. 20, pp. 679-686.

31. Verbeke, W., Vermeir, I., Pieniak, Z., Brunsø, K. (2005), Consumers' quality perception as a basis for fish market segmentation in Belgium (No. 05/351), Ghent University, Faculty of Economics and Business Administration.

32. Verhoef, P. C., Reinartz, W. J., Krafft, M. (2010), "Customer engagement as a new perspective in customer management", Journal of service research, Vol. 13 No. 3, pp. 247-252.

33. Zeqiri, J., Kareva, V., Alija, S. (2020), "The Impact of Blended Learning on Students' Performance and Satisfaction in South East European University", in Proceedings of the ENTRENOVA-ENTerprise REsearch InNOVAtion Conference, Vol. 6 No. 1, pp. 233-244.

\section{About the authors}

Adelina Emini is a Ph.D. candidate at the University of Prishtina in Kosovo. She manages International relations at Radio Television of Kosovo (RTK), and at the same time, directs the Academy of Leadership Sciences in Switzerland for Albania, Kosovo, and North Macedonia. She is a co-founder of the Academy of Leadership and Diplomacy in Pristina, Kosovo. She has lectured at University for Business and Technology for three years and currently lecturing at the Academy of Leadership Sciences in switzerland. The author can be contacted at email adelinaemini@gmail.com

Dr. Jusuf Zeqiri holds the position of Associate Professor of Marketing and International Business at the South East European University in Tetovo, Macedonia. Dr. Zeqiri has more than 20 years of teaching experience in various institutions. He has been teaching for 18 years at the undergraduate and graduate levels at South East European University in Tetovo, Macedonia. He held lectures as a Visiting Professor at many domestic and international educational institutions in the region of Southeast Europe. He has supervised many students in their master's and doctorate thesis. Dr. Zeqiri has published many research papers in peer-reviewed scientific journals and is a reviewer for many international journals. The author can be contacted at email j.zekiri@seeu.edu.mk 